\title{
NeW ASPECTS OF CLINICAL PATHOLOGY AND ELECTRO-PHYSIOLOGICAL MUSCLE DISTURBANCES IN PATIENTS WITH HISTORY OF TRICHINELLOSIS
}

\author{
KOCIECKA W.*, BOMBICKI K.**, PIELOK L.* \& GUSTOWSKA L.***
}

\section{Summary :}

Clinical studies performed in 44 patients, one, three, four, six or seven years after they had experienced trichinellosis demonstrated the persistence of various general and motor ailments in $88.7 \%$ of the patients. The persisting for many years antibodies against $\mathrm{E} / \mathrm{S}$ antigen of Trichinella in $86.4 \%$ of examined patients seem to reflect chronic stimulation by the larvae which, as shown by parasitological and histopathological tests, survived longer and underwent gradual destruction in muscles. Bio-electric disturbances in muscles were most frequently of a mixed type, with prevalence of a neural type record. These observations illustrate a disturbed function of motor neurones and of impulse transmission at the myoneural junction in patients chronically infected with Trichinella.

KEY WORDS : late sequels, electromyography, electro-neurography, pathomorphology.

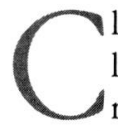
linical pathology of the late stage of trichinellosis as well as the sequels following an experienced Trichinella invasion have been focusing attention of many clinicians since the sixties (Cox et al., 1960; Boron et al., 1969; Gerwel et al., 1970; Chodera et al., 1974; Kassur et al., 1969; Kociecka et al., 1975; Kostrzewski et al., 1975). The interest in the subject reflected the need to explain complaints reported by patients even a few years after experiencing trichinellosis. Variable and not quite precise immunoserological techniques, methods of muscle bio-electric studies and non-standardised principles of treatment in the acute stage of trichinellosis created a significant obstacle in reaching consensus on trichinellosis sequels. Interesting data were provided by contemporary clinical investigations (Fröscher et al., 1988; Harms et al., 1993; Marinculic et al., 1994; Kociecka et al., 1997), based mainly on detection of antibodies against Trichinella E/S antigen using ELISA techniques, on broader clinical observations and on patho-morphological studies of muscles.

\footnotetext{
* Clinic of Parasitic and Tropical Diseases,

** Department of Pathophysiology,

*** Department of Clinical Pathomorphology, University of Medical Sciences, Przybyszewskiego 49, Poznan, Poland.

Correspondence: W. Kociecka, Clinic of Parasitic and Tropical Diseases, KMUMS, Przybyszewskiego 49, Poznan, Poland.
}

The present study aimed at evaluation of bio-electric disturbances and of patho-morphological lesions in muscles in patients with protracted complaints.

\section{MATERIAL AND METHODS}

T The studies were performed on 44 patients hospitalised, from one to seven years earlier for acute trichinellosis, in the Clinic for Parasitic and Tropical Diseases. The group included 20 women from 26 to 54 years old (mean: $41.75 \pm 9.78$ years) and 24 men from 20 to 48 years old (mean: $37.58 \pm 11.02$ years). Health status of the patients was appraised in the retrospective and current analyses. Current analysis included clinical criteria (frequency and type of general and motoric complaints) and laboratory results (basic routine and biochemical tests, including creatine kinase (CK) and lactic dehydrogenase (LDH) activities. Antibodies against $\mathrm{E} / \mathrm{S}$ antigen of Trichinella $s p$. were titrated by ELISA test (Microtiter Kit, LMD Labs, Carlsbad) and expressed in OD units. OD of 0.0 to 0.39 was scored as a negative result, that of 0.40 to 1.20 as a weakly positive result, while strongly positive results were associated with ODs above 1.20. Muscle biopsy ( $m$. deltoideus) was performed in 16 patients after obtaining an informed consent for the procedure. In all cases, trichinoscopy and histopathochemical studies of muscle samples were performed. Muscle bio-electric tests included electromyography (EMG) and electroneurography (ENG), and were performed by using skin contact electrodes and a three channel electromyograph (DISA) on rectus muscles of thighs, tibial muscles, gastrocnemius muscles, extensor muscles of toes. ENG studies included peroneal and tibial nerves on each extremity. Parameters evaluated by EMG included a) a proper contraction amplitude of a muscle, accepting as a norm the range of 500 to $1000 \mu \mathrm{V}$, b) complete (with full range of potentials) and incomplete (with few potentials examined) interference of potentials. ENG studies allowed to evaluate conductance in motoric fibres (normal values: $40-50 \mathrm{~m} / \mathrm{s}$ ) and the evoked potential amplitude (normal values: 3000- 
$5000 \mu \mathrm{V}$ ). Lowered values of the parameters indicated a pathological process. Other possible causes for the reported complaints were excluded in all patients.

\section{RESULTS}

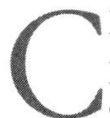
linical signs/symptoms were reported by the patients within a few years after experiencing trichinellosis: muscle pains of upper and lower extremities or, less frequently, of the trunk in 33 patients (75.0\%), muscle tiredness in 12 patients (27.2\%), general weakness in eight patients $(18.1 \%)$, numbness and swarming of upper and lower extremities in six patients $(13.6 \%)$, hyperhidrosis in five patients (11.3\%), chronic sub-febrile condition and cardiac pain in one patient $(2.3 \%)$. Detailed analysis of clinical signs and symptoms, as related to the period elapsed after the acute trichinellosis, showed that most complaints were reported one to four years after the invasion. In total, chronic clinical signs and symptoms were observed in $39(88.7 \%)$ of the examined patients. Positive ELISA tests were obtained in 38 patients (86.4\%); in 10 patients (22.7\%) the ELISA tests yielded weakly positive results (mean OD of $0.83 \pm 0.21$ ) while in 28 other patients $(63.7 \%)$ the results were strongly positive (mean OD of $2.1 \pm 0.5$ ). In six patients, the ELISA test was negative.

Results of EMG and ENG studies are given on tables I and II.

In $61.3 \%$ to $88.7 \%$ of the patients, an incomplete interference was noted and was compatible with a decreased muscle strength. From $11.3 \%$ to $31.8 \%$ of the patients had a lowered amplitude of muscle contraction. A significant proportion of patients showed lowered conduction velocity in peroneal nerves, which might reflect a disturbed function of the motor neu- rone and a damage of the myelin sheath. A decrease of evoked potential amplitude was recorded in $45.2 \%$ and $52.3 \%$ patients, indicating a functional elimination of muscle cells and axonopathy. Thus, a disturbed impulse transmission at the myo-neural junction could not be excluded. A disturbed muscle bio-electric record was detected in $84 \%$ of the 44 patients, involving most frequently a mixed, myoneural pathology $(59.0 \%$ ), less frequently a neural ( $20.4 \%$ patients) or primary muscular ( $4.6 \%$ patients) pathology.

Parasitological examination of muscles by trichinoscopy in nine cases showed the presence of Trichinella larvae, with traits of calcification in eight cases. Histopathological examination showed presence of a basophilic transformation and of cellular infiltrates in seven persons. In five patients proliferation of connective tissue was noted and in one case, muscle cells atrophy was found.

\section{DISCUSSION}

T The pattern of clinical pathology in the distant period following trichinellosis includes the persistence of clinical signs/symptoms of general and motoric types. Most cases were associated with presence of IgG class antibodies against Trichinella sp. antigen. Muscle pathology included not only the presence of larvae, most frequently with traits of destruction and calcification, but also a persisting basophilic transformation of muscle cells and cell infiltrates. The new element noted in this study concerns bio-electric disturbances of the muscular system. In contrast to the present prevalent opinion, the chronic pathology of trichinellosis includes not only a myogenic but also the neural impairment. In ENG records, decreased

\begin{tabular}{|c|c|c|c|c|c|c|}
\hline \multirow[b]{3}{*}{ Studied muscles } & \multicolumn{4}{|c|}{ Amplitude of muscle contraction } & \multicolumn{2}{|c|}{ Interference } \\
\hline & \multicolumn{2}{|c|}{$500-1000 \mu \mathrm{V}$} & \multicolumn{2}{|c|}{$<500 \mu \mathrm{V}$} & \multirow{2}{*}{$\begin{array}{c}\text { incomplete } \\
\text { n (\%) }\end{array}$} & \multirow{2}{*}{$\begin{array}{c}\text { complete } \\
\mathrm{n}(\%)\end{array}$} \\
\hline & $\mathrm{n}$ & $\%$ & $\mathrm{n}$ & $\%$ & & \\
\hline \multicolumn{7}{|l|}{ Rectus muscle of thigh } \\
\hline right $\quad \mathrm{n}=37$ & 28 & 75.7 & 9 & 24.3 & $32(86.4)$ & $5(13.5)$ \\
\hline $\mathrm{n}=37$ & 31 & 83.7 & 6 & 16.2 & $32(86.4)$ & $5(13.5)$ \\
\hline \multicolumn{7}{|l|}{ Tibialis muscle } \\
\hline right $\mathrm{n}=44$ & 38 & 86.3 & 6 & 13.7 & $39(88.7)$ & $5(11.3)$ \\
\hline $\mathrm{n}=44$ & 39 & 88.7 & 5 & 11.3 & $39(88.7)$ & $5(11.3)$ \\
\hline \multicolumn{7}{|l|}{ Gastrocnemius muscle } \\
\hline right $\quad n=44$ & 34 & 77.2 & 10 & 22.8 & $27(61.3)$ & $17(38.7)$ \\
\hline $\mathrm{n}=44$ & 35 & 79.5 & 9 & 20.4 & $38(86.3)$ & $6(13.7)$ \\
\hline \multicolumn{7}{|l|}{ Extensor muscle of toes } \\
\hline $\mathrm{n}=44$ & 30 & 68.1 & 14 & 31.8 & $38(86.3)$ & $6(13.7)$ \\
\hline $\mathrm{n}=43$ & 30 & 69.8 & 13 & 30.2 & $37(86.0)$ & $6(14.0)$ \\
\hline
\end{tabular}

Table I. - Electromyography in 44 persons with history of trichinellosis. 


\begin{tabular}{|c|c|c|c|c|c|c|c|c|}
\hline \multirow[b]{3}{*}{ Studied peripheral nerves } & \multicolumn{4}{|c|}{ Conduction velocity in motor fibres } & \multicolumn{4}{|c|}{ Amplitude of evoked potential } \\
\hline & \multicolumn{2}{|c|}{$40-50 \mathrm{~m} / \mathrm{s}$} & \multicolumn{2}{|c|}{$<40 \mathrm{~m} / \mathrm{s}$} & \multicolumn{2}{|c|}{$3000-5000 \mu \mathrm{V}$} & \multicolumn{2}{|c|}{$<3000 \mu \mathrm{V}$} \\
\hline & $\mathrm{n}$ & $\%$ & $\mathrm{n}$ & $\%$ & $\mathrm{n}$ & $\%$ & $\mathrm{n}$ & $\%$ \\
\hline \multicolumn{9}{|l|}{ Peroneal nerve } \\
\hline right $\quad n=42$ & 37 & 88.0 & 7 & 16.6 & 23 & 54.7 & 19 & 45.2 \\
\hline $\mathrm{n}=42$ & 40 & 95.2 & 2 & 4.8 & 20 & 47.6 & 22 & 52.3 \\
\hline \multicolumn{9}{|l|}{ Tibial nerve } \\
\hline $\mathrm{n}=38$ & 31 & 81.6 & 7 & 18.4 & 36 & 94.8 & 2 & 5.2 \\
\hline $\mathrm{n}=38$ & 34 & 89.4 & 4 & 10.5 & 35 & 22.1 & 3 & 7.8 \\
\hline
\end{tabular}

Table II. - Electroneurography in 44 persons with history of trichinellosis.

amplitude of evoked potentials deserved particular attention, suggesting a disturbed conduction velocity at the myo-neural junction.

The presence of antibodies against Trichinella antigen in patients who experienced trichinellosis earlier is explained by the long survival of Trichinella larvae in muscles. Their presence or their progressive destruction (Gerwel et al., 1970; Chodera et al., 1974; Fröscher et al., 1988; Harms et al., 1993; Kociecka et al., 1997) represent the source of antigen which will stimulates IgG antibody production for a few years (Marinculic et al., 1994).

The results of our study indicate a complex nature of the late period of trichinellosis, which may produce long lasting sequels. The complex pathological phenomenon, which does not end with Trichinella larvae encapsulation in muscles, may result in various ailments, affecting in particular the motor system. The late sequels of trichinellosis reflected also delayed and insufficient anthelmintic treatment during the acute stage of the disease.

\section{ACKNOWLEDGEMENTS}

W e are indebted to Bozena Mrozewicz, $\mathrm{PhD}$ and to Urszula Lesicka, MBiol from the Serological Lab of our Clinic for performing ELISA tests.

\section{REFERENCES}

Boron P. \& Jezyna C. From case reports of chronic trichinellosis forms (metatrichinellosis) (in Polish). Wiadomosci Parazytologiczne, 1968, 14, 201-206.

Cox P.P., Schultz M.G., Kagan I.G. \& Preizler J. Trichinosisfive years serologic and clinical follow-up. American Journal of Epidemiology, 1969, 88, 651-657.

Chodera L., Gerwel CZ., Kociecka W. \& Pawlowski Z. On the problem of late clinical sequele of human trichinellosis. Wiadomosci Parazytologiczne, 1974, 20, 125-131.
Fröscher W., Gullota P., SaAthoff M. \& Tackmann W. Chronic trichinosis. Clinical, bioptic, serological and electromyographic observations. European Neurology, 1988, $28,221-226$.

Gerwel Cz., Kociecka W. \& PAwlowski Z.S. Parasitological examinations of muscles several years after trichinosis. Epidemiological Reviews, 1970, 24, 262-269.

Harms G., Binz P., Feldmeier H., Zwingenberger K., Schleehauf D., Dewes W., Kress-Hermesdorf I., Klindworth C. \& BIENZLE U. Trichinosis: a prospective controlled study of patients ten years after acute infection. Clinical Infectious Diseases, 1993, 17, 637-643.

KAssur B. \& JANuszkieWICZ J. Clinical classification of trichinellosis. Epidemiological Reviews, 1969, 15, 750-751.

Kassur B., Malik A. \& KowAlCZYK W. Health condition of persons with trichinellosis history. Wiadomosci Parazytologiczne, 1969, 15, 740-748.

Kassur B. \& Januszkiewicz J. On the inappropriateness of the idea of chronic trichinellosis. Epidemiological Reviews, 1970, 24, 68-75.

Kociecka W., Kaczmarek J., Stachowski B. \& Gustowska L. Electromyographic studies in persons with trichinellosis history. Wiadomosci Parazytologicznye, 1975, 21, 721-730.

Kociecka W., Mrozewicz B., Gustowska L. \& Jakuszewska D. Late sequele of trichinellosis: clinical and pathomorphological findings, in: Trichinellosis. Ortega- Pierres G., Gamble H.R., Van Knapen F.\& Wakelin D. (eds), Centro de Investigacion.y Estudios Avanzados del Instituto Politecnico Nacional Mexico, 1997, 611-621.

Kostrzewski J.M., Politowicz J., Gancarz , Plonka W. \& JedrZEJEWSKA E. Trichinellosis epidemics in Zielona Gora in 1972 (in Polish). Przeglad Epidemiologiczne, 1975, 29, 57 64.

KozAr Z., SLADKi E. \& ZAK D. Clinical aspects of chronic trichinellosis in people. II. Studies in patients with chronic disease of motoric system. Wiadomosci Parazytologiczne, $1964,10,665-667$

Marinculic A., Lucinger S., Milas J., Efenberger-Marinculic P., Bruschi F., Sturlan S., Rozic M., Milas V. \& Valpotic I. Persistence of immune response in patients chronically affected by trichinellosis, in: Trichinellosis. Campbell WC, Pozio E., Bruschi F. (eds), Istituto Superiore di Sanita Press, Rome, Italy, 1994, 347-351. 